Original Contribution

\title{
ASSESSMENT OF RELATIONS BETWEEN CERTAIN INCUBATION QUALITIES OF TURKEY EGGS THROUGH CORRELATION AND REGRESION ANALYZES
}

\author{
P. Hristakieva ${ }^{1^{*}}$, N. Keranova ${ }^{2}$ \\ ${ }^{1}$ Agricultural Institute, Stara Zagora, Bulgaria \\ ${ }^{2}$ Faculty of Economics, Agricultural University-Plovdiv, Bulgaria
}

\begin{abstract}
The present study was developed based on data from eggs incubation from three lines of turkeys: Layer Light turkey - LL, Meat Heavy turkey -MH and North Caucasian Bronze Turkey - NCB at 36 weeks of age. The degree of influence of the incubation traits was determined: number of set eggs, number of fertilized eggs, number of dead embryos $1^{\text {st }}$ review and number of dead embryos $2^{\text {nd }}$ review on the number of hatched turkeys by applying a correlation analysis. The obtained relations were presented by mathematical models compiled after using a regression analysis. The significant dependencies between these signs were demonstrated by mathematical models compiled using regression analysis. Mathematical models were built to present these relations in analytical form.
\end{abstract}

Key words: turkey eggs, incubation, hatch, fertility, correlation analysis, regression analysis

\section{INTRODUCTION}

At the core of a selection in animal breeding is the study of the genotype and phenotype of the individuals. The genotype is the totality of all the genes of the individual obtained through the sex cells of the parents. The phenotype is the totality of all signs formed under the influence of the genotype itself and the impact of external conditions. The various signs in birds are inherited to a various degree. Highly inheritable signs are: weight and color of the eggs; Average inheritable signs are: body weight and meat quality, and low and very low inheritable signs are the so-called reproductive signs: age of first laying, laying intensity, fertility and hatchability of eggs. The fertility and hatchability of eggs are key indicators of the reproductive qualities of poultry lines used to produce breeding eggs. The heritability coefficient of these traits is very low (0.060.13 ), which indicates that these signs are strongly influenced by non-genetic factors (1). Stromberg, 1975, (2) found that hatchability and fertilization of bird eggs are most sensitive to the influence of external factors and are very poorly influenced by genetic factors. Anumerous authors had shown that incubation

\footnotetext{
*Correspondence to: P. Hristakieva, Agricultural Institute, Stara Zagora, 6000,

E-mail:poly_31@abv.bg,
}

qualities of the birds eggs are influenced by the conditions of the environment: of the age oflaying (3-6); of the quality of the eggs $(7,8)$; of the storage time of the eggs (9-13) etc. Eslick and McDaniel (14) established a correlation between the number of fertilized eggs and the dead embryos in their study of the incubation qualities of hen eggs. McDaniel et al. (15) reported a positive correlation between the fertilization and hatchability of broilers breeder eggs. For low-inheritable signs, the individual selection is ineffective; therefore selectionists resort to calculating the correlation coefficients and the regression between the signs. Ramaphala and Mbajiorgu (16) studied hen eggs by building mathematical models. The authors aim at determining the influence of egg weight on hatchability. They divide the eggs into three groups: small (weighing below $49 \mathrm{~g}$ ), medium (weighing between 50 and $59 \mathrm{~g}$ ) and large (weighing 60 to $69 \mathrm{~g}$ ). Following a regression analysis, a linear regression model was obtained through which the relation between the size of an egg, the hatchability indicators and the weight of the hatched chickens was determined. Correlations between the different periods associated with the genotype features are determined by the formula:

$r g=\frac{\operatorname{cov}_{g(i, j)}}{\sqrt{\operatorname{var}_{g(i, i)} \times v a r_{g(j, j)}}}$ 
where $\operatorname{cov}_{g(i, j)}$ is the genetic covariant egg production in $\mathrm{i}$ and $\mathrm{j}$ period; $\operatorname{var}_{g(i, i)}$ is additive genetic variance for i period.

The goals of this work are connected with establishing the degrees of relation between the traits: number of set eggs, number of fertilized eggs, number of hatched turkeys, number of dead embryos $1^{\text {st }}$ review and number of dead embryos $2^{\text {nd }}$ review during the incubation of eggs from three lines of turkeys lines. Building mathematical models presenting the aforementioned relations in analytical form.

\section{MATERIALS AND METHODS}

Animals and study design. The present study was conducted in the turkey farm at the Agricultural Institute in the town of Stara Zagora in the section "Selection of Population Genetics and Technologies of Poultry and Rabbits". Eggs from three lines of turkeys at 36 weeks of age were used as test material: Layer Light turkey - LL, Meat Heavy turkey $\mathrm{MH}$ and North Caucasian Bronze turkey NCB. The breeding of the turkeys was carried out on deep non-removable litter at a bird density of 3 pcs. $\mathrm{m}^{-2}$. They were fed with a standard blend for layer turkeys with metabolizable energy $-12.55 \mathrm{MJ} / \mathrm{kg}$, crude protein $-18.10 \%$, calcium $-2.87 \%$, available phosphorus $-0.49 \%$ at an average consumption of $300 \mathrm{~g}$ per day. They were artificially inseminated twice a week with $0.025 \mathrm{ml}$ of fresh semen, undiluted. The eggs from the daily production from the three lines were subjected to fumigation, sorting and selection before entering the hatchery for incubation. The incubation of eggs was carried out in incubator " Optima ". At the $1^{\text {st }}$ review - on the 9th day of the setting, the non-fertilized eggs were removed. At the $2^{\text {nd }}$ review - on the 15 th day from the beginning of the incubation, the dead embryos were removed. On the 25th day the eggs were transferred to the hatchery for group hatching. On the 28th day, of the day of hatching were counted number of turkeys. Statistical analysis. The goals set at the beginning of the study were achieved through the consistent application of correlation and regression analyzes. The correlation analysis is a classic method for determining the degree of dependence between two variables. The Pearson-Brave correlation coefficient is used in the present work. It is calculated according to the formula:

$$
r=\frac{\sum_{i=1}^{n}\left(Y_{i}-\bar{Y}\right)\left(X_{i}-\bar{X}\right)}{\sqrt{\sum_{i=1}^{n}\left(Y_{i}-\bar{Y}\right)^{2} \sum_{i=1}^{n}\left(X_{i}-\bar{X}\right)^{2}}},
$$

where: $\bar{X}, \bar{Y}$ are the arithmetic mean of the two variables. With this coefficient, it is assumed that the two examined variables are linearly dependent. This, in turn, means that the pairs of measurements considered as points in the two-dimensional plane are grouped around a straight line. Given the presence of statistically proven correlations between the individual traits, a linear regression analysis was applied to them. Through it, the relations between the factor and the independent variables for each of the studied lines of turkeys were obtained in an analytical form. The statistical program product IBM Statistics SPSS 23 (17- 20) was used for the mathematical data processing.

\section{RESULTS AND DISCUSSIONS}

The strength of the correlation and the degree of significance of the respective correlation coefficient between the number of hatched turkeys and the rest of the traits for Heavy meat turkeys are given in Table 1. It is found that this number is in strong correlation with the number of set eggs and the number of fertilized eggs at proven levels of significance, respectively lower than 0.05 and 0.01 . Taking into account the determination coefficient, it appeared that $77 \%$ of the alteration in the number of hatched turkeys was due to the alteration in the number of the set eggs, and $91 \%$ of the alteration in the number of hatched turkeys was affected by the alteration in the fertilized eggs. Moreover, both relations are one-way because of the positive sign of the respective correlation coefficient.

Table 1. Correlation coefficients and degrees of significance in Heavy meat turkeys (MH)

\begin{tabular}{|l|l|l|l|l|l|}
\hline Parameters & $\begin{array}{l}\text { Number of } \\
\text { hatched } \\
\text { turkeys }\end{array}$ & $\begin{array}{l}\text { Number of } \\
\text { set eggs }\end{array}$ & $\begin{array}{l}\text { Number of } \\
\text { fertilized eggs }\end{array}$ & $\begin{array}{l}\text { Embryonic } \\
\text { death } \\
(0-9 \text { days })\end{array}$ & $\begin{array}{l}\text { Embryonic } \\
\text { death } \\
(10-15 \text { days })\end{array}$ \\
\hline $\begin{array}{l}\text { Number of hatched } \\
\text { turkeys }\end{array}$ & 1 & $0.879^{*}$ & $0.952^{*}$ & 0.496 & 0.786 \\
\hline Number of set eggs & 0.050 & 1 & $0.975^{* *}$ & 0.846 & 0.792 \\
\hline Number of fertilized eggs & 0.013 & 0.005 & 1 & 0.722 & 0.759 \\
\hline $\begin{array}{l}\text { Embryonic death } \\
(0-9 \text { days })\end{array}$ & 0.395 & 0.071 & 0.169 & 1 & 0.544 \\
\hline $\begin{array}{l}\text { Embryonic death } \\
(10-15 \text { days })\end{array}$ & 0.115 & 0.110 & 0.136 & 0.344 & 1 \\
\hline
\end{tabular}

*at significance level $\mathrm{p}<0.05^{* *}$; at significance level $\mathrm{p}<0.01$ 
These results justify the use of linear regression analysis on the experimental data to obtain the analytical form of the relation between the number of hatched turkeys (y) on the one hand and the number of set eggs (F1) and the number of fertilized eggs (F2) on the other hand. The experimental data satisfy the Kolmogorov-Smirnov criterion for normal distribution. This, from mathematical point of view, is a necessary condition for implementing a regression analysis.

The resulting linear relation is given through the following linear regression model: $\mathrm{y}=-16.001-0.736 \mathrm{~F}_{1}+1.908 \mathrm{~F}_{2}$.

It was found that both the given model and the regression coefficients involved in it are statistically significant.

As a result of the correlation analysis carried out on the experimental data providing information about the tested indicators in Layer light turkeys, a very high correlation was found between the number of hatched turkeys and the number of set eggs, and the correlation coefficient (0.940) is statistically significant (with a degree of significance, 0.018) as it is smaller than the error, equal to 0.05 (Table 2).

Table 2. Correlation coefficients and degrees of significance in Layer light turkeys (LL)

\begin{tabular}{|l|l|l|l|l|l|}
\hline Parameters & $\begin{array}{l}\text { Number of } \\
\text { hatched } \\
\text { turkeys }\end{array}$ & $\begin{array}{l}\text { Number of } \\
\text { set eggs }\end{array}$ & $\begin{array}{l}\text { Number of } \\
\text { fertilized eggs }\end{array}$ & $\begin{array}{l}\text { Embryonic } \\
\text { death } \\
\text { (0-9 days })\end{array}$ & $\begin{array}{l}\text { Embryonic } \\
\text { death } \\
\text { (10-15 days })\end{array}$ \\
\hline $\begin{array}{l}\text { Number of hatched } \\
\text { turkeys }\end{array}$ & 1 & $0.940^{*}$ & $0.904^{*}$ & 0.695 & 0.335 \\
\hline Number of set eggs & 0.018 & 1 & $0.963^{* *}$ & 0.469 & 0.282 \\
\hline $\begin{array}{l}\text { Number of fertilized } \\
\text { eggs }\end{array}$ & 0.035 & 0.009 & 1 & 0.324 & 0.469 \\
\hline $\begin{array}{l}\text { Embryonic death } \\
\text { (0-9 days) }\end{array}$ & 0.192 & 0.426 & 0.595 & 1 & -0.099 \\
\hline $\begin{array}{l}\text { Embryonic death } \\
\text { (10-15 days) }\end{array}$ & 0.581 & 0.646 & 0.426 & 0.874 & 1 \\
\hline
\end{tabular}

*at significance level $\mathrm{p}<0.05 ; * *$ at significance level $\mathrm{p}<0.01$

A very high correlation was also found between the number of hatched turkeys and the number of fertilized eggs (0.904), also statistically significant (significance level equal to 0.035 ). It turned out that $88 \%$ of the alteration in the number of hatched turkeys was due to the alteration in the number of set eggs and $82 \%$ - to the number of fertilized eggs. All this gives reason to subject the obtained data to regression analysis, in order to present the relation between the analyzed indicators in analytical form.

After applying a regression analysis, it was found that the obtained linear regression model:

$\mathrm{y}=-7.584+0.730 \mathrm{~F}_{1}-0.007 \mathrm{~F}_{2}$,

presenting the relation between the number of set eggs $\left(F_{1}\right)$, the number of fertilized eggs $\left(F_{2}\right)$ and the number of hatched turkeys (y) is statistically insignificant due to a degree of significance greater than the error, the regression coefficients in that model are also statistically insignificant.

Table 3 gives the correlation coefficients presenting the degree of relation between the number of hatched turkeys for NCB turkeys.
The calculated correlation coefficients show very high correlations between the number of hatched turkeys and the number of set eggs ( $R$ $=0.986)$ and fertilized eggs $(\mathrm{R}=0.997)$, both of which are statistically proven at a significance level of 0.003 and 0.000 respectively, less than the error $\alpha=0.05$. After defining the coefficient of determination, it was found that $96 \%$ of the alteration in the number of hatched turkeys was due to the alteration in the number of set eggs, and this relation is $99 \%$ in the number of fertilized eggs. Due to the positive correlation coefficients in both cases, it can be asserted that the obtained relations are one-way.

The data related to the incubation indicators of NCB turkeys meet the necessary conditions, mentioned earlier in the exposition, for carrying out a regression analysis. The resulting linear regression model is statistically significant due to a degree of significance (0.004), smaller than the error $\alpha=0.05$. The analytically derived relation between the number of hatched turkeys (y), the number of set eggs $\left(F_{1}\right)$ and the number of fertilized eggs $\left(\mathrm{F}_{2}\right)$ is as follows: 


\section{HRISTAKIEVA P., et al.}

$\mathrm{y}=-3.515+0.109 \mathrm{~F}_{1}+0.672 \mathrm{~F}_{2}$.

The regression coefficients in the mathematical model are also statistically significant. Considering the values of the standardized coefficients $\beta$, corresponding to each of the regression coefficients, it can be asserted that the number of fertilized eggs has greater influence on the number of hatched turkeys.

Table 3. Correlation coefficients and degrees of significance for NCB turkeys

\begin{tabular}{|l|l|l|l|l|l|}
\hline Parameters & $\begin{array}{l}\text { Number of } \\
\text { hatched } \\
\text { turkeys }\end{array}$ & $\begin{array}{l}\text { Number of } \\
\text { set eggs }\end{array}$ & $\begin{array}{l}\text { Number of } \\
\text { fertilized } \\
\text { eggs }\end{array}$ & $\begin{array}{l}\text { Embryonic } \\
\text { death } \\
(0-9 \text { days })\end{array}$ & $\begin{array}{l}\text { Embryonic } \\
\text { death } \\
(10-15 \text { days })\end{array}$ \\
\hline $\begin{array}{l}\text { Number of hatched } \\
\text { turkeys }\end{array}$ & 1 & $0.982^{* *}$ & $0.997^{* *}$ & -0.111 & 0.489 \\
\hline Number of set eggs & 0.003 & 1 & $0.976^{* *}$ & -0.231 & 0.432 \\
\hline $\begin{array}{l}\text { Number of fertilized } \\
\text { eggs }\end{array}$ & 0.000 & 0.004 & 1 & -0.054 & 0.431 \\
\hline $\begin{array}{l}\text { Embryonic death } \\
\text { (0-9 days) }\end{array}$ & 0.889 & 0.769 & 0.946 & 1 & 0.120 \\
\hline $\begin{array}{l}\text { Embryonic death } \\
(10-15 \text { days })\end{array}$ & 0.403 & 0.468 & 0.469 & 0.880 & 1 \\
\hline
\end{tabular}

*at significance level $\mathrm{p}<0.05$; ** at significance level $\mathrm{p}<0.01$

\section{CONCLUSIONS}

After applying a correlation analysis on the data from the incubation of eggs from the three lines of turkeys, very high, statistically proven correlations between the number of hatched turkeys on the one hand and the number of set eggs and the number of fertilized eggs on the other hand were obtained. All this determines the application of linear regression analysis. The built mathematical models regarding Meat Heavy turkeys and NCB turkeys, as well as the respective regression coefficients involved, are statistically significant. The results of this study could be the basis for future scientific developments in the field.

\section{REFERENCES}

1. Sapp, R., Rekaya, R., Misztal, I., Wing, T., Male and female fertility and hatchability in chickens: a longitudinal mixed model approach. Poultry Science 83 (8): 12531259, 2004.

2. Stromberg, J., A Guide to Better hatching, Stromberg , Publ. Co. Iowa, USA :8-25, 1975.

3. Christensen V.L., Donaldson W.E., McMurtry J.P., Physiological differences in late embryos from turkey breeders at different ages. Poultry Science 75: 172178, 1996.

4. Peebles E. D., Doyle S. M., Zumwalt C. D., Gerard P. D., Latour M. A., Boyle C. R., Breeder age influences embryogenesis in broiler hatching eggs. Poultry Science 80:272-277, 2001.

5. Orlowska, A., Mróz E., Effect of age of turkey-hens and egg storage period on embryo mortality and poults quality. Proc. XVIII International Poultry Symposium PB
WPSA, Rogów, Poland, 4-6.09.2006,: 4954, 2006.

6. Ulmer - Franco A.M., Fasenko G.M., O 'DeaChristopher E.E., Hatching egg characteristics, chick quality and broiler performance at 2 breeder flock ages and from 3 egg weights. Poultry Science 89: 2735-2742, 2010.

7. Mróz E., Puchajda K., Pudyszak K., Structure and pigmentation of egg shell and biological value of turkey hatching eggs. Polish Journal of Natural Sciences 10: 141-152, 2002.

8. Mróz,E. Michalak, K., Orłowska, A., Embryo mortality and poult quality depend on the shell structure of turkey hatching eggs. Animal Science Papers and Reports 25, 3: 161-172, 2007.

9. Hristakieva P., Lalev M., Oblakova M., Mincheva N., Ivanova I., Effect of storage duration on the quality of hatching turkey eggs. Archiva Zootechnica 14: 57-65, 2011

10.Christensen V.L., Grimes J.L., Wineland M.J., Davis G.S., Accelerating embryonic growth during incubation following prolonged egg storage.1. Embryonic livability. Poultry Science 82: 1869-1878, 2003.

11.Madeddu M., Zaniboni L., Magiagalli M.G., Cassinelli C., Cerolini S., Egg related parameters affecting fertility and hatchability in the Italian bantam breed Mericanel della Brianza. Animal Reproduction Science 137: 214-219, 2013.

12.Bakst, M. R., Welch, G. R., Camp, M. J., Observations of turkey eggs stored up to 27 days and incubated for 8 days: embryo developmental stage and weight differences 
and the differentiation of fertilized from unfertilized germinal discs. Poultry Science 95, 5: 1165-1172, 2016.

13.Stępińska, M., Mróz, E., Krawczy, M., Otowski, K., Górska, A., Effect of hen age and storage time on egg weight loss and hatchability results in turkeys. Annals of Animal science, 17, 2: 447-462, 2017.

14.Eslick, M.L., McDaniel, G.R., Interrelationship between fertility and hatchability of eggs from broiler breeder hens. Applied Poultry Science 15:123-214, 1992.

15.McDaniel, G. R., Brake, J., Eckman, M.K., Factors Affecting Broiler Breeder Performance: 4. The Interrelationship of
Some Reproductive Traits. Poultry Science, 60, 8: 1792-1797, 1981.

16.Ramaphala, N., Mbajiorgu, C., Effect of Egg Weight on Hatchability and Chick Hatch-weight of COBB500 Broiler Chickens, Asian Journal of Animal and Veterinary Advances 8, 7, 885-892, 2013.

17.Field, A., Discovering Statistics using IBM SPSS Statistics, Mobile Study, London, 2013.

18.Meyers, L., Gamst, G., Guarino, A., Performing Data Analysis Using IBM SPSS, Wiley, 2013.

19. Weinberg S. L., Abramowitz S. K., Statistics Using IBM SPSS, An Integrative Approach, Cambridge University Press, 2016. 